\title{
Deadaption and readaptation with lactose, but no cross-adaptation to lactulose: A case of occult colonic bacterial adaptation
}

\author{
Andrew Szilagyi MD ${ }^{1}$, Albert Cohen $\mathrm{MD}^{1}$, Christina Vinokuroff $\mathrm{PDt}^{2}$, Darakhshan Ahmad PhD ${ }^{3}$, \\ Usha Nathwani $\mathrm{PDt}^{2}$, Samara Yesovitch $\mathrm{BA}^{1}$
}

\begin{abstract}
A Szilagyi, A Cohen, C Vinokuroff, D Ahmad, U Nathwani, $\mathrm{S}$ Yesovitch. Deadaption and readaptation with lactose, but no cross-adaptation to lactulose: A case of occult colonic bacterial adaptation. Can J Gastroenterol 2004;18(11):677-680.
\end{abstract}

\begin{abstract}
The standard $3 \mathrm{~h}$ breath hydrogen $\left(3 \mathrm{hBH}_{2}\right)$ test distinguishes lactose maldigesters from lactose digesters. However, multiple factors impact on $\mathrm{BH}_{2}$ and care is needed to exclude a priori variables. When these factors are controlled, a negative $\mathrm{BH}_{2}$ test implies lactase persistent status or lactase nonpersistent status with colonic adaptation. A case of a Sicilian man who tested negative (lactase persistent status confirmed) on an initial $50 \mathrm{~g}$ lactose challenge is described. It was observed that he consumed $28.1 \mathrm{~g}$ lactose/day before testing. He subsequently underwent five additional challenge tests in the course of the next 10 months. In four tests the dose intake of lactose was varied upon instruction, and in the fifth test a $30 \mathrm{~g}$ lactulose challenge was carried out. It was demonstrated that on radically decreasing lactose intake, a full lactase nonpersistent status was unmasked. Output of $3 \mathrm{hBH}_{2}$ varied inversely with daily lactose intake. Finally, at a time when he was readapted to lactose, there was no discernible adaptation to lactulose challenge. It was concluded that 'occult' colonically adapted subjects may contribute to negative $\mathrm{BH}_{2}$ tests. There is a relationship between variation in lactose intake and the results of $\mathrm{BH}_{2}$ testing. Finally, there was no cross-adaptation to lactulose challenge when lactose was used as the adapting sugar.
\end{abstract}

Key Words: Colonic bacterial adaptation; Lactose; Lactulose

\section{Désadaptation et réadaptation au lactose, sans adaptation croisée au lactulose : cas d'adapta- tion bactérienne colique occulte}

\begin{abstract}
Le test $3 \mathrm{hBH}_{2}$ standard (test d'hydrogène respiratoire de trois heures) permet de distinguer les sujets qui digèrent bien ou mal le lactose. Or, comme plusieurs facteurs influent sur le $\mathrm{BH}_{2}$ et il faut veiller à exclure certaines variables préalables. Lorsque ces facteurs sont contrôlés, un test $\mathrm{BH}_{2}$ négatif signifie « persistance de lactase » ou «non-persistance de lactase avec adaptation du côlon ». On décrit ici le cas d'un Sicilien chez qui les tests étaient négatifs (persistance de lactase confirmée) lors d'une exposition initiale à $50 \mathrm{~g}$ de lactose. On a observé qu'il consommait 28,1 $\mathrm{g}$ de lactose par jour avant le test. Il a par la suite subi cinq autres tests au cours des dix mois suivants. Lors de quatre de ces tests, la prise de lactose a varié selon les instructions données, et pour le cinquième, un test de provocation au moyen de $30 \mathrm{~g}$ de lactulose a été effectué. On a pu démontrer que lors d'une baisse radicale de l'apport en lactose, on démasquait la nonpersistance totale de lactase. L'excrétion au test $3 \mathrm{hBH}_{2}$ variait de façon inversement proportionnelle à l'apport quotidien en lactose. En dernier lieu, à un moment où le patient a été réadapté au lactose, on n'a noté aucune adaptation notable lors de l'exposition au lactulose. On en a conclu que certains sujets présentant une adaptation occulte du côlon contribuaient aux résultats négatifs des tests $\mathrm{BH}_{2}$. Il existe un lien entre la variation de l'apport en lactose et les résultats aux tests $\mathrm{BH}_{2}$. En terminant, on n'a noté aucune adaptation croisée lors de l'exposition au lactulose, quand du lactose était utilisé comme sucre pour l'étape d'adaptation.
\end{abstract}

$\mathrm{T}$ he standard test for lactose maldigestion is the measurement of exhaled breath hydrogen $\left(\mathrm{BH}_{2}\right)$ for $3 \mathrm{~h}$ after an aqueous lactose challenge $(1,2)$. A positive test is interpreted as a sustained rise of hydrogen $20 \mathrm{ppm}$ above the baseline (3). Some authors (4) argue that a more sensitive test can be obtained if the sustained rise is $10 \mathrm{ppm}$ above the baseline. The results of $\mathrm{BH}_{2}$ tests, however, can be affected by multiple factors $(3,5)$. Most result in false-negative outcomes. However, if conditions that exclude any variables affecting intestinal transit (eg, narcotics, untreated hypothyroidism, diabetes mellitus and pregnancy) or microbial flora (previous ingestion of antibiotics or elemental diets) are ensured in the month before testing, a negative $\mathrm{BH}_{2}$ test usually indicates appropriate lactase persistent status or possible a priori colonic bacterial adaptation.
The concept of colonic bacterial adaptation to lactose intolerance has been reported by a number of authors $(6,7)$; however, the formal description and definition were published by Hertzler and Savaiano (8). In their study, lactose-intolerant subjects were fed increasing amounts of lactose, up to $1 \mathrm{~g} / \mathrm{kg} /$ day for 16 days. The comparison of measured exhaled hydrogen before and after the adaptation period showed that genetic lactose maldigesters were converted to phenotypic lactose digester status. This adaptive process was attributed to an expansion and metabolic alteration of fecal microbial flora specifically involving bifidobacteria and lactobacilli (9-11).

The microbial floral alterations in these lactic acid-producing bacteria have been associated with possible health benefits to the host (12,13). A further impetus to considering colonic

${ }^{1}$ Division of Gastroenterology, Department of Medicine; ${ }^{2}$ Departmentt of Dietetics, Sir Mortimer B Davis Jewish General Hospital, McGill

University, School of Medicine, Montreal; ${ }^{3}$ Institut national de la recherché scientique - Institut Armand Frappier, Centre de microbiologie et biotechnologie, Université du Québec, Pointe-Claire, Quebec

Correspondence and reprints: Dr Andrew Szilagyi, Division of Gastroenterology, Department of Medicine, Sir Mortimer B Davis Jewish General Hospital, 3755 Cote Ste-Catherine, room G-327, Montreal, Quebec H3T 1E2. Telephone 514-340-8144, fax 514-340-8101,

e-mail aszilagy@gas.jgh.mcgill.ca

Received for publication June 22, 2004. Accepted August 4, 2004 


\begin{tabular}{|c|c|c|c|c|c|}
\hline $\begin{array}{l}\text { Lactose } \\
\mathrm{BH}_{2} \text { date } \\
(\mathrm{m} / \mathrm{d} / \mathrm{y})\end{array}$ & $\begin{array}{c}\text { Daily } \\
\text { intake (g/day) }\end{array}$ & $\begin{array}{l}\text { Baseline } \mathrm{H}_{2} \\
\quad(\mathrm{ppm})\end{array}$ & $\underset{(\mathrm{ppm})}{\sum 3 \mathrm{hBH}_{2}}$ & $\begin{array}{c}\text { Total } \\
\text { symptom } \\
\text { score }\end{array}$ & Diarrhea \\
\hline $07 / 25 / 03$ & 28.1 & 0 & 10 & 2 & 0 \\
\hline $10 / 07 / 03$ & 1.5 & 3 & 285 & 4 & 0 \\
\hline $11 / 04 / 03$ & 16.5 & 5 & 117 & 5 & 0 \\
\hline $12 / 18 / 03$ & 28.0 & 2 & 154 & 4 & 0 \\
\hline $05 / 05 / 04$ & 53.3 & 1 & 56 & 0 & 0 \\
\hline \multicolumn{6}{|c|}{$\begin{array}{c}\text { Lactulose } \mathrm{BH}_{2} \\
\text { date }(\mathrm{m} / \mathrm{d} / \mathrm{y})\end{array}$} \\
\hline $05 / 12 / 04$ & 37.7 & 25 & 425 & 6 & 1 \\
\hline
\end{tabular}

$\mathrm{m} / \mathrm{d} / \mathrm{y}$ Month/Day/Year

adaptation as beneficial derives from a comparison of lactose ingestion with the ingestion of a prebiotic in lactase nonpersistent (LNP) subjects (14). In addition, we have previously demonstrated that lactose maldigestion can be improved by feeding prebiotic lactulose to lactose-intolerant subjects for three weeks (15).

We have maintained in previous publications $(16,17)$ that unrecognized colonic bacterial adaptation to lactose in LNP subjects may play a role in protection against certain intestinal diseases. To date, subjects who were reported to be adapted colonically were prospectively followed from a position of no or limited adaptation and restudied after they were given dairy products. We now report a case of a Sicilian man who represents a case of 'occult' colonic adaptation. We also had the opportunity to study the effects of quantitatively manipulating lactose intake and compare the effect of colonic adaptation on lactulose handling.

\section{CASE PRESENTATION}

A 32-year-old man was referred in May 2003 for gastroenterological evaluation to one of the authors $(\mathrm{AC})$ because of intermittent abdominal pain and bloating over a two-year period. There was no history of diarrhea or weight loss but there was mild nausea. The patient had no other known medical conditions. He had quit smoking two years earlier, but smokes a cigarette on rare occasions. He did not take any medications and specifically denied ingestion of narcotics or antibiotics. There was no significant family history of celiac or Crohn's disease or other serious illnesses. Physical examinations revealed a healthy man without any localized findings.

An earlier upper gastrointestinal barium meal was normal, as was a later gastroscopy with a negative urease test for Helicobacter pylori. His blood chemistries and complete blood count were all within normal limits. Serum thyroid stimulating hormone was normal. He was asked to undergo a lactose $\mathrm{BH}_{2}$ test.

\section{STUDY OUTLINE AND METHODS}

At the Sir Mortimer B Davis Jewish General Hospital (Montreal, Quebec) carbohydrate maldigestion and absorption is measured weekly by using a sugar challenge and recording exhaled $\mathrm{BH}_{2}$ over a $3 \mathrm{~h}$ period. Subjects are asked to fast (except water) overnight after consuming a low carbohydrate diet for supper. As well, participants are asked not to smoke during the test. After a baseline measurement, subjects are asked to consume a test carbohydrate (in this case lactose) mixed in approximately $250 \mathrm{~mL}$ to $350 \mathrm{~mL}$ of added water. Subsequently, exhaled $\mathrm{BH}_{2}$ is measured every $15 \mathrm{~min}$ for a total of $90 \mathrm{~min}$, and then every $30 \mathrm{~min}$ until another $90 \mathrm{~min}$ has elapsed (180 $\mathrm{min}$ in total). Symptoms at each time interval are recorded and graded from 0 to 3 (nil, mild, moderate and severe) in the case of bloating, gas and cramps, and 0 or 1 for diarrhea. The $\mathrm{BH}_{2}$ is measured using a handheld chemical sensor for $\mathrm{H}_{2}$ (EC60 gastrolyzer, Bedfont Scientific Ltd, United Kingdom) with a range of 0 ppm to 2000 ppm and previously validated against gas chromatography (18).

The present study, to assess the impact of average daily target sugar on the results of $\mathrm{BH}_{2}$, has been carried out since October 2002. The study consists of application of an ethics boardapproved demographic, $24 \mathrm{~h}$ and three-day diet recall questionnaire (19). Subjects who undertake a lactose $\mathrm{BH}_{2}$ test fill out a specific questionnaire targeting food items containing lactose. (Other carbohydrates such as fructose and sorbitol are subjects of other questionnaires.)

The current subject participated in the study from July 25, 2003 to May 12, 2004. He agreed to undertake a total of six $3 \mathrm{~h}$ breath tests. During the period of follow-up, he did not report any acute illnesses. After the initial test, he was instructed to either drastically reduce or drastically increase his dairy intake for four additional lactose tests. A questionnaire was filled out with each test. The sixth test was a $30 \mathrm{~g}$ lactulose challenge, again with recording of average lactose intake during the $3 \mathrm{~h}$ test. In each case, except the time interval between the highest lactose intake (53 g/day) and the lactulose test challenge, the alteration in dietary intake of lactose spanned approximately two to three weeks. In the last instance, one week elapsed but he was asked not to alter his dairy intake.

The sum of $\mathrm{BH}_{2}$ for $3 \mathrm{~h}\left(\Sigma 3 \mathrm{hBH}_{2}\right)$ was calculated for each of the six tests by adding the results from each 30 min interval after subtracting the respective baselines. Total symptom score as well as individual symptoms were recorded. A SAS statistical package employing the Pearson correlation method was used to compare the results of average daily lactose intake with the results of $\Sigma 3 \mathrm{hBH}_{2}$ for lactose.

\section{RESULTS}

The initial $\Sigma 3 \mathrm{hBH}_{2}$ was $10 \mathrm{ppm}$. This result is clearly negative (genotypic or phenotypic lactase persistent subject). However, there was a single rise in $\mathrm{BH}_{2}$ to $10 \mathrm{ppm}$ at $45 \mathrm{~min}$ and this was coincidentally associated with flatus as recorded by the subject.

Based on his ethnic background (Sicily), he had an approximately $50 \%$ or more chance of being an LNP subject $(20,21)$. It is noted in Table 1 that his average daily intake of lactose was $28.1 \mathrm{~g} /$ day (equivalent to more than $500 \mathrm{~mL} /$ day of milk). It was decided that the subject should subsequently undergo further tests. He was instructed to decrease lactose intake to one $29.5 \mathrm{~mL}$ coffee creamer a day and then to increase to usual levels and finally to increase to maximum tolerated levels. There was a marked rise in $\Sigma 3 \mathrm{hBH}_{2}$ after drastic reductions of lactose intake. However a negative $\Sigma 3 \mathrm{hBH}_{2}$ test only occurred with maximum $53.3 \mathrm{~g} /$ day lactose intake (Figure 1). Finally, at a time when he was asked to continue with a high lactose intake, results from a lactulose challenge test did not parallel the results seen for lactose. Symptom scores were worse with lactulose than lactose challenges. 


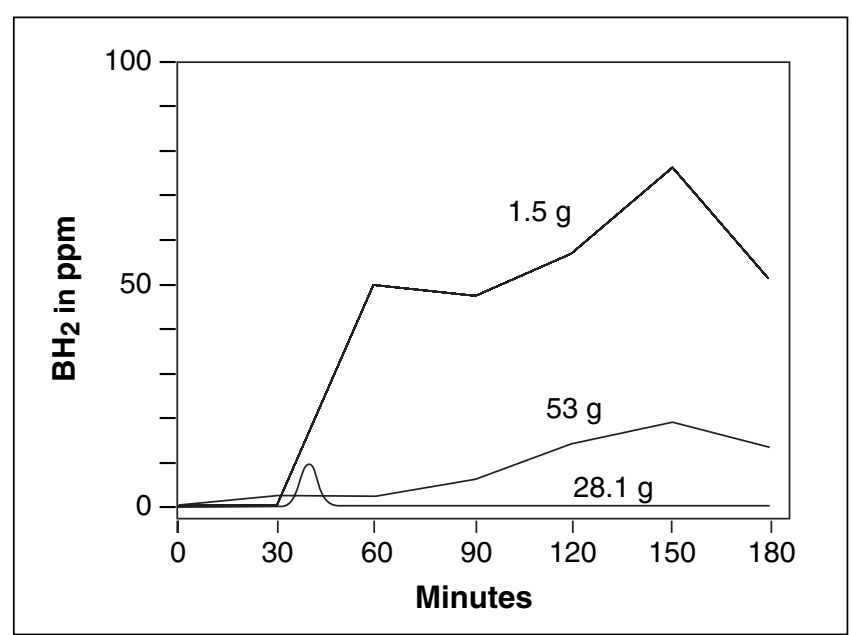

Figure 1) The individual breath hydrogen $\left(\mathrm{BH}_{2}\right)$ results in response to wide variation in daily average lactose intake (three-day recall) is shown ( $g /$ day). While the first test result with ingestion of $28.1 \mathrm{~g}$ lactose/day before a $50 \mathrm{~g}$ lactose challenge is clearly negative, with ingestion of $1.5 \mathrm{~g} /$ day the test result is clearly positive. Increasing the intake to $53 \mathrm{~g} /$ day in an effort to readapt the subject resulted in a post-challenge curve which would be suspicious for possible adaptation. However, it does not meet some clinical criteria for a positive test because the peak never reaches 20 ppm above baseline within the confines of the $3 \mathrm{~h}$ standard test

Figure 2 demonstrates the correlation between lactose intake and $\Sigma 3 \mathrm{hBH}_{2}$ tests. While there was a high correlation $(r=-0.739)$, this failed to reach significance, primarily due to the large variations between the first and fourth tests.

\section{DISCUSSION}

The present case report constitutes a modified N1 trial of daily lactose intake and its impact on $\mathrm{BH}_{2}$ prediction (22). There are three observations of interest. First, we described the case of a subject with occult colonic adaptation independent of laboratory conditions. We cannot prove that unknown additional factors influenced the very first lactose challenge test. However, the sudden appearance of a $10 \mathrm{ppm} \mathrm{BH}_{2}$ blip coincidentally associated with symptoms of gas at $45 \mathrm{~min}$ would be a most unusual event with all previous and subsequent values registering 0 . This coincidence, although not meeting any conventional criteria of positivity, suggested that this subject may be colonically adapted. Because he had an approximately $50 \%$ or more chance of being an LNP subject, the ingestion of more than $500 \mathrm{~mL}$ equivalent of milk per day supported the notion of adaptation. The subsequent full unmasking of genetic LNP status was confirmed by restricting lactose intake for several weeks before the next test.

The second observation is the suggestive evidence that $\Sigma 3 \mathrm{hBH}_{2}$ responds to the manipulation of quantitative intake of lactose before the test. The association of increasing lactose intake with decreasing $\mathrm{BH}_{2}$ result in the present report is weak despite the negative $\mathrm{r}$ value. The lack of significance likely relates to a variable response to a $28 \mathrm{~g} /$ day lactose intake which failed to achieve complete readaptation. This was only achieved with the maximum tolerated doses of lactose. The explanation for this is not readily apparent. Variability of $\mathrm{H}_{2}$ production, a failure of direct correlation

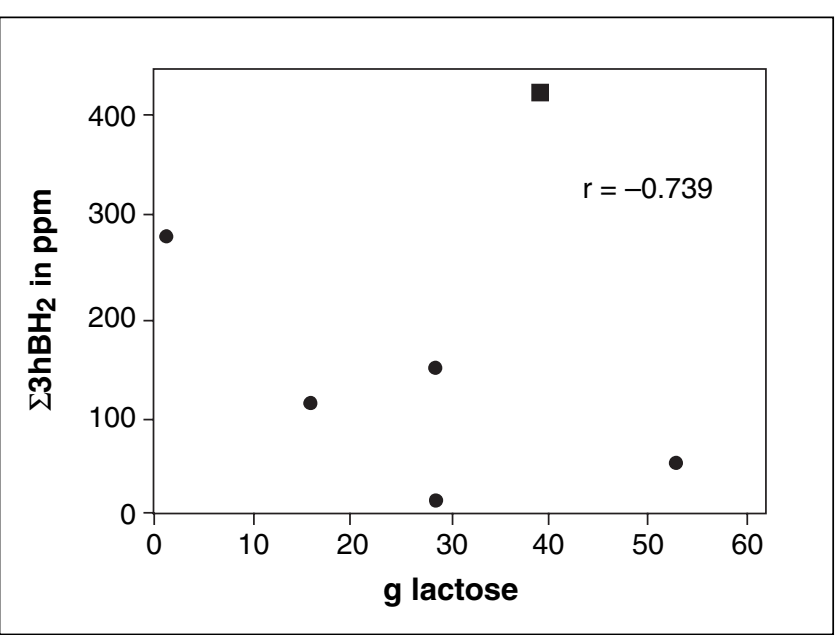

Figure 2) A scatter plot of summed $3 \mathrm{~h}$ breath hydrogen $\left(\Sigma 3 \mathrm{hBH}_{2}\right)$ in response to a $50 \mathrm{~g}$ lactose challenge test is shown in comparison with prior daily average (three-day recall) grams of lactose intake $(\bullet)$. While a high negative correlation is found, the $P$ value is 0.15 , likely due to the large variation in $\mathrm{BH}_{2}$ response to $28 \mathrm{~g} /$ day of lactose ingestion before the tests. A $30 \mathrm{~g}$ lactulose challenge ( $\mathbf{m}$ ) shows the highest $3 \mathrm{hBH}_{2}$ of all tests at a time when the subject was readapted with the highest doses of prior lactose intake

with fecal B-galactosidase, a marker for bacterial expansion (23) and a possible time effect on metabolic function of adapting bacteria all may play a role in outcome. Nevertheless, in absolute terms the deadaptation by withholding lactose and readaptation by increasing lactose intake to maximum, strongly support the negative correlation of prior ingestion on subsequent magnitude of $\mathrm{H}_{2}$ production in tests.

The third observation of interest is the unexpected failure of this lactose-adapted subject to also adapt to the lactulose challenge. Lactulose is derived from lactose (24). Lactose and lactulose have equal effects on the improvement of hepatic encephalopathy in cirrhotic patients (25) and improving lactose intolerance either by adapting with lactose $(8,26)$ or lactulose (15). The above observations were hypothetically linked through similar microbial effects of the two sugars in previous studies. Thus, it was expected that there may be mutual metabolic equality at a time when the LNP subject was maximally lactose adapted. More formal clinical studies could further examine the effects of both lactose and lactulose on lower intestinal flora. However, until proven otherwise, our observation suggests that adaptation of bacteria with lactose leads to the induction of a more restricted metabolic pathway expansion or a different bacterial species which does distinguish between lactose and lactulose.

In summary, we present a patient with genetic lactose maldigestion who may represent an example of occult colonic bacterial adaptation as defined by a standard $3 \mathrm{hBH}_{2}$ test. The observations further suggest an inverse effect of dietary lactose manipulation on bacterial lactose metabolism. Finally we suggest that adaptation with lactose may stimulate a more specific metabolic pathway than adaptation with lactulose.

ACKNOWLEDGEMENTS: The authors thank Ms Xiaoqing Xue for statistical help and Ms Florence Lurie for secretarial services. 


\section{REFERENCES}

1. Newcomer AD, McGill DB, Thomas PJ, Hofman AF. Prospective comparison of indirect methods for detecting lactase deficiency. N Engl J Med 1975;293:1232-6.

2. Casellas F, Malagelada JR. Applicability of short hydrogen breath test for screening of lactose malabsorbtion. Dig Dis Sci 2003;48:1333-8.

3. Romagnuolo J, Schiller D, Bailey RJ. Using breath tests wisely in a gastroenterology practice: An evidence-based review of indications and pitfalls in interpretation. Am J Gastroenterol 2002;97:1113-26.

4. Strocchi A, Corazza G, Ellis CJ, Gasbarrini G, Levitt MD. Detection of malabsorption of low doses of carbohydrate: Accuracy of various breath $\mathrm{H}_{2}$ criteria. Gastroenterology 1993;105:1404-10.

5. Szilagyi A. Review article: Lactose - a potential prebiotic. Aliment Pharmacol Ther 2002;16:1591-602.

6. Habte D, Sterky G, Hjalmarsson B. Lactose malabsorption in Ethiopian children. Acta Paediatr Scand 1973;62:649-54.

7. Sadre M, Karbasi K. Lactose intolerance in Iran. Am J Clin Nutr 1979;32:1948-54.

8. Hertzler SR, Savaiano DA. Colonic adaptation to daily lactose feeding in lactose maldigesters reduces lactose intolerance. Am J Clin Nutr 1996;64:232-6.

9. Ito M, Kimura M. Influence of lactose on faecal microflora in lactose maldigesters. Microb Ecol Health Dis 1993;6:73-6.

10. Jiang $T$, Savaiano DA. In vitro lactose fermentation by human colonic bacteria is modified by Lactobacillus acidophilus supplementation. J Nutr 1997;127:1489-95.

11. Jiang T, Savaiano DA. Modification of colonic fermentation by bifidobacteria and $\mathrm{pH}$ in vitro. Impact on lactose metabolism, short-chain fatty acid and lactate production. Dig Dis Sci 1997;42:2370-7.

12. Hove H, Norgaard H, Morensen PB. Lactic acid bacteria and the human gastrointestinal tract. Euro J Clin Nutr 1999;53:339-50.

13. Dunne C. Adaptation of bacteria to the intestinal niche: Probiotics and gut disorder. Inflamm Bowel Dis 2001;7:136-45.

14. Szilagyi A. Redefining lactose as a conditional prebiotic. Can J Gastroenterol 2004;18:163-7.

15. Szilagyi A, Rivard J, Fokeeff K. Improved parameters of lactose maldigestion using lactulose. Dig Dis Sci 2001;46:1509-19.
16. Szilagyi A. Altered colonic environment, a possible predisposition to colorectal cancer and colonic inflammatory bowel disease: Rationale of dietary manipulation with emphasis on disaccharides. Can J Gastroenterol 1998;12:133-46.

17. Szilagyi A. Colonically adapted lactose maldigesters may bias dietary studies of colorectal cancer. Dig Dis Sci 1998;43:39-40.

18. Peuhkuri K, Poussa T, Korpela R. Comparison of a portable breath hydrogen analyser (Micro H2) with a Quintron MicroLyzer in measuring lactose maldigestion, and the evaluation of a Micro $\mathrm{H} 2$ for diagnosing hypolactasia. Scand J Clin Lab Invest 1998;58:217-24.

19. Stunkard AJ, Waxman M. Accuracy of self-reports of food intake. J Am Diet Assoc 1981;79:547-51.

20. Scrimshaw NS, Murray EB. The acceptability of milk and milk products in populations with a high prevalence of lactose intolerance. Am J Clin Nutr 1988;48(4 Suppl):1079-159.

21. Bozzani A, Penagini R, Velio P, et al. Lactose malabsorption and intolerance in Italians. Clinical implications. Dig Dis Sci 1986;31:1313-6.

22. McLeod RS, Taylor DW, Cohen Z, Cullen JB. Single-patient randomised clinical trial. Use in determining optimum treatment for patient with inflammation of Kock continent ileostomy reservoir. Lancet 1986;1:726-8.

23. Suarez FL, Savaiano DA. Lactose digestion and tolerance in adult and elderly Asian-Americans. Am J Clin Nutr 1994;59:1021-4.

24. Montgomery EM, Hudson CS. Relations between rotatory power and structure in the sugar group XXVII: Synthesis of a new disaccharide ketose (lactulose) from lactose. J Am Chem Soc 1930;52:2101-6.

25. Uribe-Esquivel M, Maran S, Poo JL, Munoz RM. In vitro and in vivo lactose and lactulose effects on colonic fermentation and portal-systemic encephalopathy parameters. Scand J Gastroenterol 1997;32(Suppl 222):49-52.

26. Pribila BA, Hertzler SR, Martin BR, Weaver CM, Savaiano DA. Improved lactose digestion and intolerance among AfricanAmerican adolescent girls fed a dairy-rich diet. J Am Diet Assoc 2000;100:524-8. 


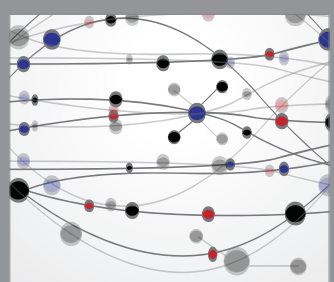

The Scientific World Journal
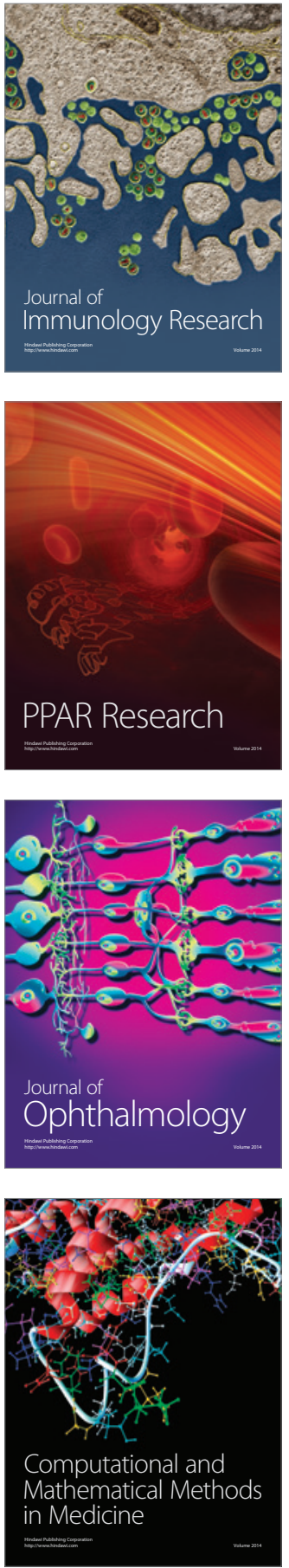

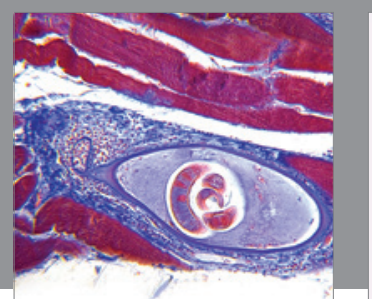

Gastroenterology Research and Practice

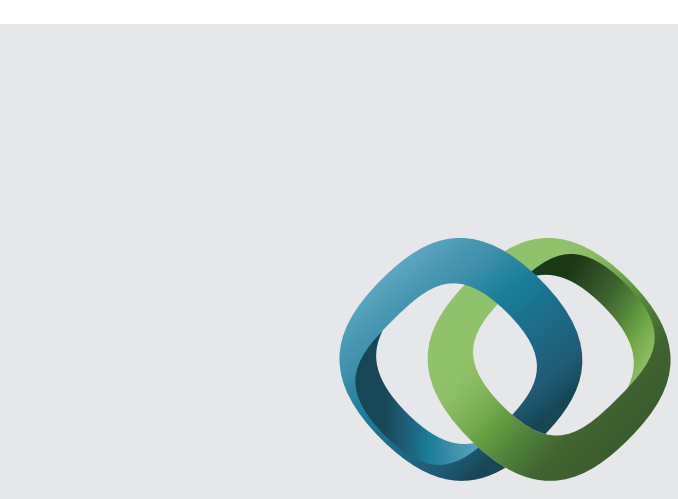

\section{Hindawi}

Submit your manuscripts at

http://www.hindawi.com
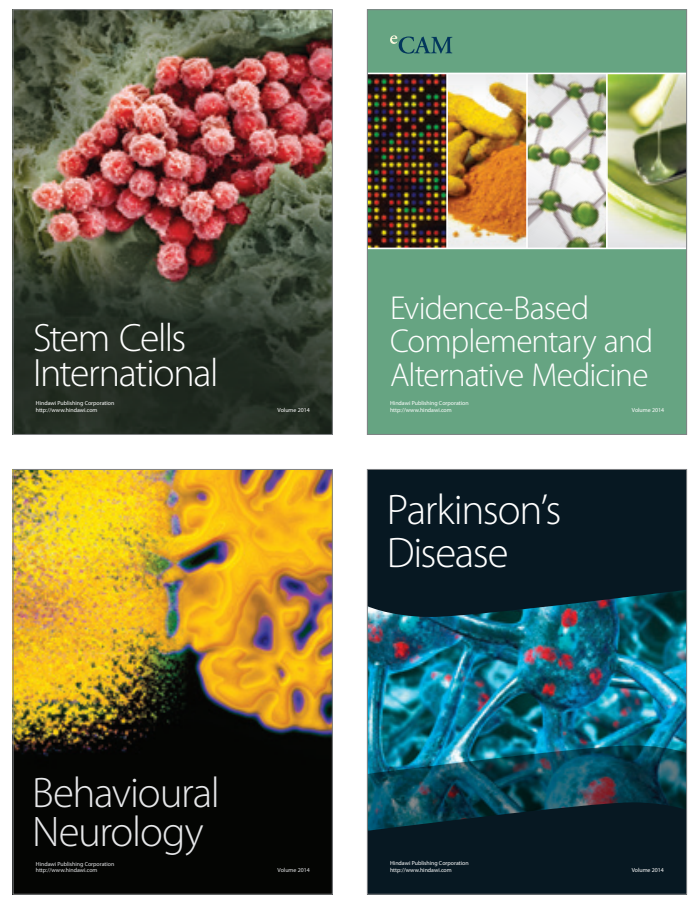
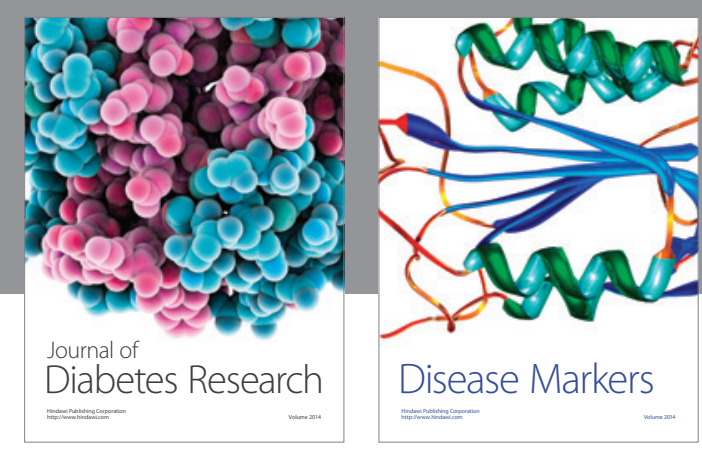

Disease Markers
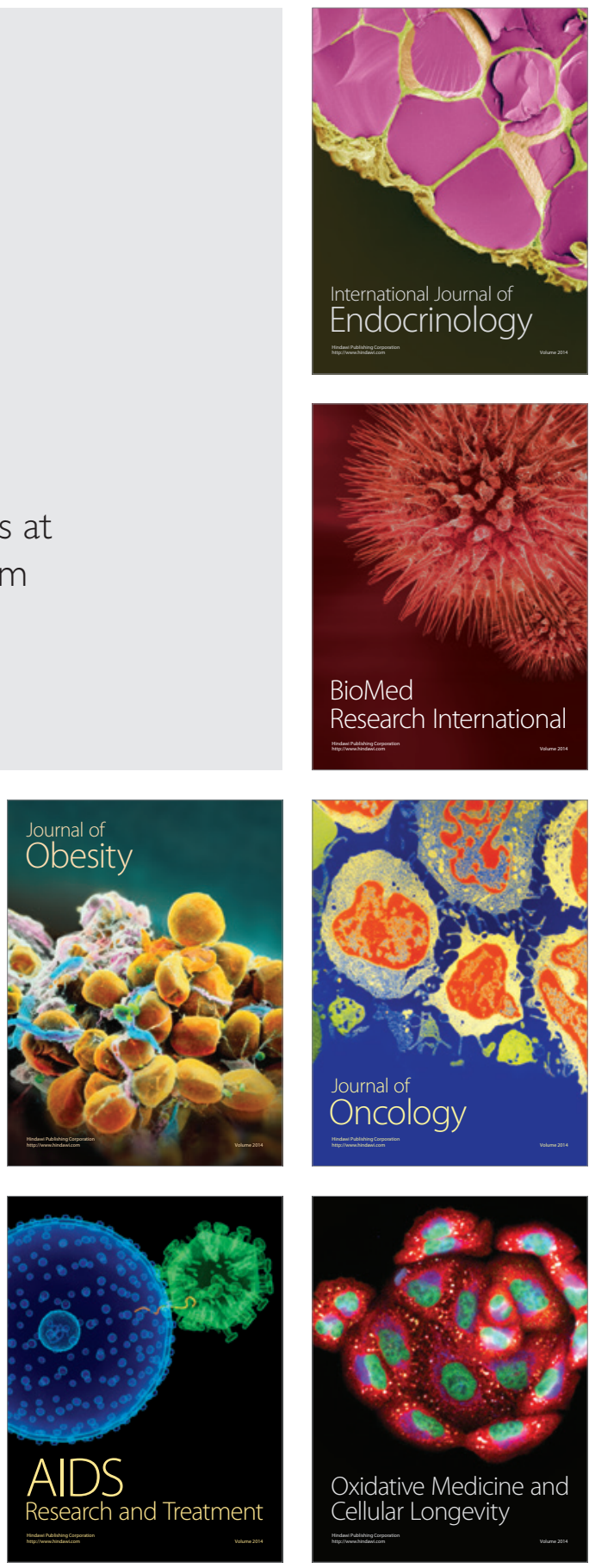